\title{
Tomasz Wyżlic
}

\section{GRANICA PRUS WSCHODNICH NA ODCINKU Z POLSKA W LATACH 1919-1922}

\author{
Słowa kluczowe: $\quad$ komisja delimitacyjna, Konferencja Ambasadorów, plebiscyt, Prusy \\ Wschodnie, traktat wersalski \\ Schlïsselwörter: $\quad$ Abgrenzungskommission, Botschafterkonferenz, Volksabstimmung, \\ Ostpreussen, Vertrag von Versailles \\ Keywords: $\quad$ delimitation committee, Conference of Ambassadors, plebiscite, Eastern \\ Prussia, Treaty of Versailles
}

Podpisany 28 czerwca 1919 r. w Sali Lustrzanej pałacu wersalskiego traktat pokojowy ustanowił nowy podział polityczny Europy. Polska uzyskała Poznańskie bez Wschowy, Babimostu, Międzyrzecza i Skwierzyny oraz większą część Prus Królewskich (w sumie $45463 \mathrm{~km}^{2} \mathrm{z}$ nieco ponad trzema milionami mieszkańców). Ustalanie granic Polski odbywało się głównie pod naciskiem niechętnego Polsce brytyjskiego premiera Davida Lloyda George’a, który przeciwstawiał się wszelkim próbom rozwiązań mogącym przyczynić się do wzrostu znaczenia roli Francji w Europie. Mocarstwa zachodnie były zainteresowane ułożeniem sobie lepszych warunków pokoju z Niemcami, przy równoczesnym rozwiązaniu problemu rosyjskiego. Możliwości ustępstw szukano kosztem słabszego partnera, czyli Polski. Rada zdecydowała o utworzeniu z Gdańska obszaru o ograniczonej suwerenności w postaci wolnego miasta. Cztery prawobrzeżne powiaty nad Wisłą nie zostały przyłączone bezpośrednio do Polski, o ich losach miał zdecydować plebiscyt, podobnie jak w przypadku Mazur i południowej Warmii. Ostateczne wyznaczenie granicy miało należeć do Mocarstw Sprzymierzonych i Stowarzyszonych ${ }^{1}$. Sejm Ustawodawczy RP, po burzliwej debacie, 31 lipca 1919 r., ratyfikował traktat pokojowy z Niemcami². Traktat pokojowy wszedł w życie 10 stycznia $1920 \mathrm{r}$.

\footnotetext{
W. Wrzesiński, Warmia i Mazury w polskiej myśli politycznej 1864-1945, s. 203.

2 Dz. U. z 1920 r. Nr 35, poz. 199, Ustawa z 31 VII 1919 r. o ratyfikacji traktatu pokoju.
} 
Przebieg linii granicy Prus Wschodnich został opisany w artykule 28 traktatu: „od punktu położonego na wybrzeżu Bałtyku około $1 \frac{112}{2} \mathrm{~km}$. na pótnoc od kościoła wsi Pröbbernau, pod kątem $159^{\circ}$ (licząc od północy ku wschodowi):

- linja, mniej-więcej dwukilometrowa do oznaczenia na miejscu;

- $\quad$ stąd $w$ linji prostej przez latarnię umieszczona w kolanie kanału elbląkiego, mniej-więcej do punktu: 54 19’1/2 północnej szerokości, 19²6’ wschodniej długości od Greenwich;

- $\quad$ stąd do najbardziej na wschód położonego ujścia Nogatu, mniej-więcej pod katem 209', liczac od północy ku wschodowi;

- $\quad$ stąd biegiem Nogatu w górę do punktu, gdzie oddziela się ta rzeka od Wisły;

- $\quad$ stąd głównem korytem żeglownem Wisły w górę, dalej południowa granica powiatu kwidzyńskiego, dalej takąż granica powiatu suskiego ku wschodowi do punktu jej zetknięcia się z dawną granica Prus Wschodnich;

- $\quad$ stąd dawna granica między Prusami Zachodniemi a Prusami Wschodniemi, dalej granica między powiatami ostródzkim a niborskim, biegiem Szkotewki w dót rzeki, dalej w górę Nidy aż do punktu położonego mniej-więcej 5 kilometrów na zachód od Białut, a najbardziej zbliżonego do dawnej granicy rosyjskiej;

- $\quad$ stąd ku wschodowi do punktu leżacego bezpośrednio na południe od przecięcia się drogi Niborg-Mława z dawna granicą rosyjską:

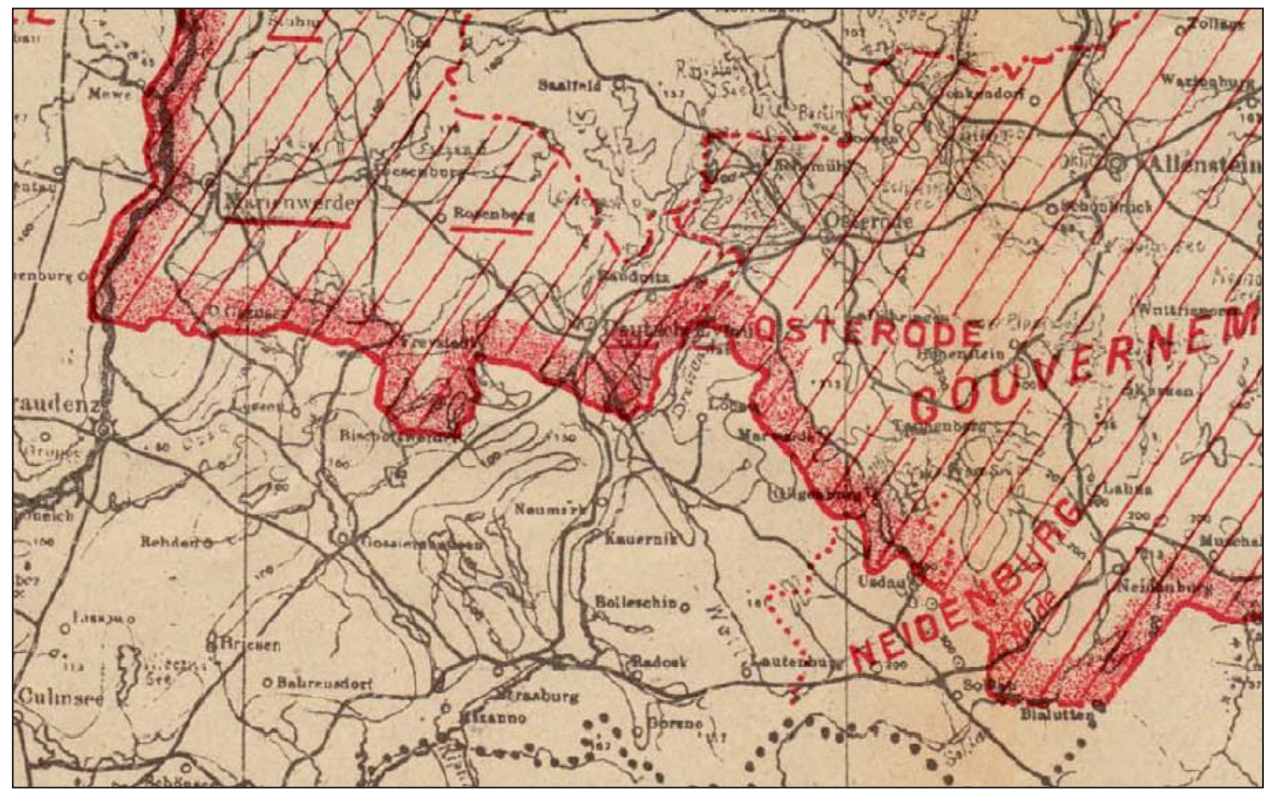

Fragment mapy dołączonej do treści Traktatu Wersalskiego z zaznaczonym przebiegiem granicy na odcinku od dawnej granicy niemiecko-rosyjskiej do Wisły. 
- $\quad$ linja, mająca się oznaczyć na miejscu, a biegnąca na pólnoc od Białut;

- $\quad$ stąd dawna granica rosyjską aż na wschód od Smolnik, dalej w dół głównego żeglownego koryta Niemna, dalej odnoga Skierwieth jego delty aż do zalewu kurońskiego;

- $\quad$ stąd linja prosta do punktu zetknięcia się wschodniego brzegu mierzei kurońskiej i granicy administracyjnej, mniej-więcej $4 \mathrm{~km}$, na południo-zachód od Nidden;

- $\quad$ stad ta granica administracyjna do zachodniego brzegu mierzei kurońskiej."

Do traktatu dołączono również mapę przedstawiającą zachodnie granice Polski.

Traktat pokojowy ustanowił także na obszarze części Prus Wschodnich i Zachodnich plebiscyt, który miał rozstrzygnąć o przynależności Warmii, Mazur i Powiśla do Polski lub Niemiec. Dopiero po zakończeniu plebiscytu Komisja Graniczna rozpoczęła prace delimitacyjne. Niekorzystny dla Polski wynik plebiscytu spowodował, że polskie zdobycze terytorialne były nieznaczne, a prace komisji skupiały się na wyznaczeniu w terenie granic ustalonych traktatem pokojowym, czyli od dawnej granicy niemiecko-rosyjskiej do Wisły, jak również odcinek Wisły do styku z Wolnym Miastem Gdańsk.

W dniu 24 października 1919 r. w Berlinie podpisano umowę o wycofaniu wojsk niemieckich z terenów przekazywanych Polsce ${ }^{3}$. Określono, że wojsko niemieckie rozpocznie wymarsz siódmego dnia o godzinie $6^{00}$ rano po wejściu w życie traktatu pokojowego. Dzień ratyfikacji nie był liczony do tego okresu. Wymarsz wojsk niemieckich i wejście wojsk polskich odbywało się strefami. Zamierzeniem stron było, aby możliwie po wyjściu wojsk niemieckich wchodziły wojska polskie, jednak w zasadzie należało unikać bezpośredniego kontaktu wojsk. Wyjście i wejście wojsk miało odbywać się jedynie w porze dziennej, tj. od godziny $6^{00}$ do godziny $18^{00}$. Na każdy dzień określano osobną linię demarkacyjną, która wyznaczała terytorium do opuszczenia przez wojska niemieckie. Wyznaczona linia demarkacyjna nie mogła być przed określonym czasem przekroczona przez wojska polskie. Obszar przekazywany Polsce podzielono na 3 strefy: strefa A do zajęcia w ciągu 3 dni; strefa B do zajęcia w ciągu dwóch następnych dni; strefa B2 do zajęcia w ciągu 4 następnych dni (dni 4, 5, 6 i 7); strefa C dzień 6 i 7 do godz. $15^{00}$; strefa D dni 9, 10, 11 i 12; strefa E dni 13, 14, 15; strefa F dni 15 i 16; strefa G dni 16, 17, 18 i 19. Jednocześnie ustalono dokładne daty przekazywania ważnych obiektów, tj. twierdza Toruń - przekazanie drugiego dnia o godz. $12^{00}$. Dworzec kolejowy Ko-

3 Politisches Archiv des Auswärtigen Amts Berlin (PAAA) R 85859 bp. [Odpis umowy o wycofaniu wojsk niemieckich z terenów przekazywanych Polsce]. Była to umowa dotycząca części wojskowej, została ona włączona do umowy podpisanej 25 XI 1919 r. w Berlinie przez Zygmunta Seydę oraz Edgarta Haniela Heimhausena w sprawie wycofania wojsk z odstąpionych obszarów i oddaniu zarządu cywilnego. Ibidem, bp. odpis informacji niemieckiego ministerstwa obrony z 23.11.1919 r. 
walewo Pomorskie trzeciego dnia o godz. $12^{00}$. Dworzec kolejowy Chełmża piątego dnia o godz. $6^{00}$. Dworzec kolejowy Kornatowo piątego dnia o godz. $16^{00}$. Stronie niemieckiej zagwarantowano, że polskie pociągi mogą przejeżdżać przez dworzec kolejowy Kowalewo Pomorskie dopiero trzeciego dnia od godz. $6^{00}$. Fordon mógł być zajęty przez polskie wojska dopiero czwartego dnia od godz. $13^{00}$. Twierdza Chełmno mogła być przekazana wojskom polskim szóstego dnia od godz. $16^{00}$, zaś siódmego od $15^{00}$ wojska polskie mogły przejąć twierdzę Grudziądz. Dzień ósmy był dniem odpoczynku dla obu stron. Wojska polskie mogły przekroczyć Wisłę pod Grudziądzem i Chełmnem dopiero dziewiątego dnia od godz. $6^{00}$. Do przejęcia ważnych obiektów wojskowych (np. twierdze Toruń, Grudziądz i Chełmno) rząd polski bezpośrednio po wejściu w życie traktatu pokojowego wysłał specjalne komisje, które miały zakończyć pracę do wyznaczonego czasu przekazania. Szczegóły przekazania stref i ochrony porządku publicznego ustalały miejscowe dowództwa

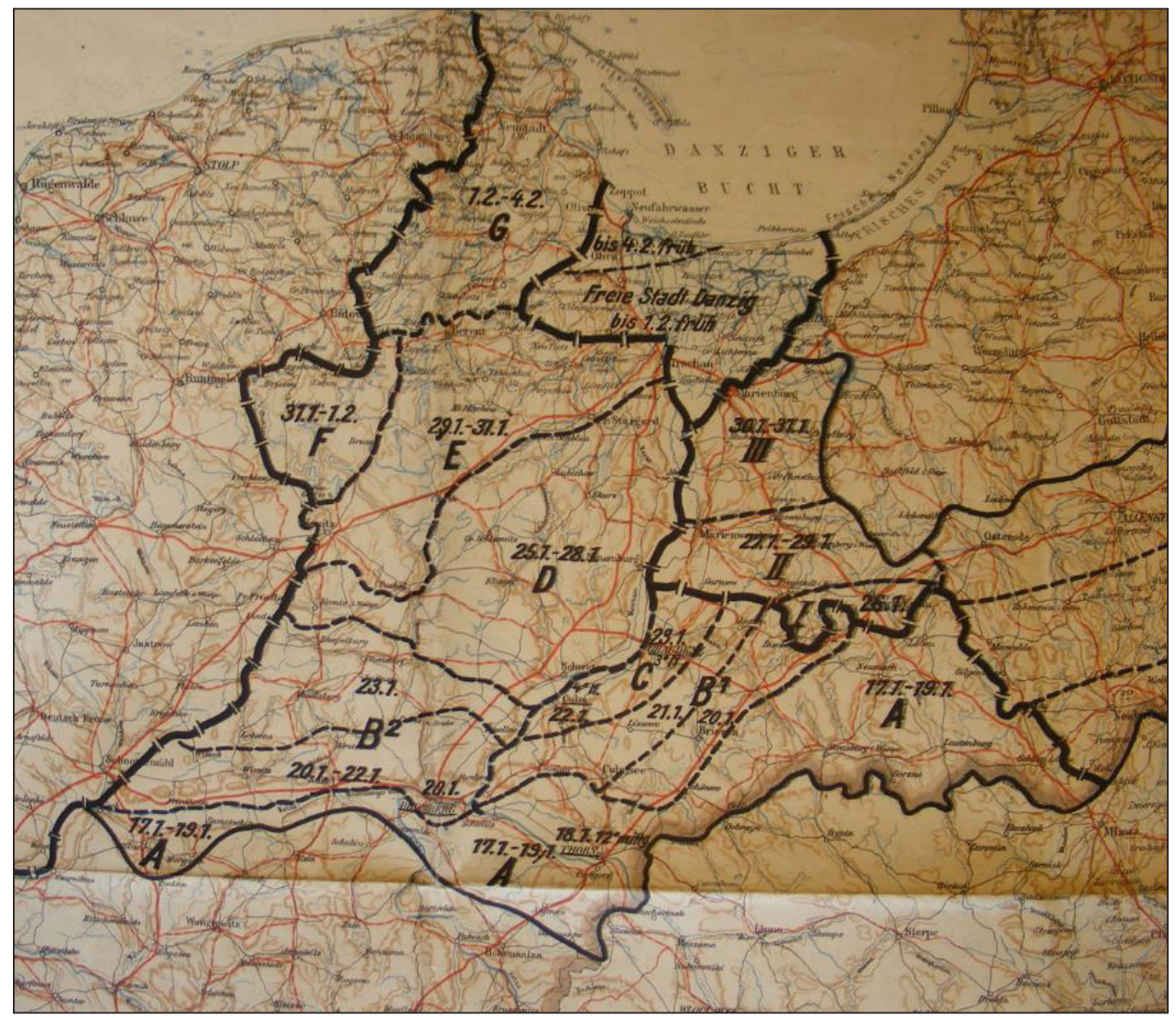

Mapa podziału terenów przekazywanych Polsce. Źródło: GStA PK, I. HA Rep I. 77 Tit. 856, Nr $254 k .150$ 
z wkraczającymi wojskami polskimi. Ze strony polskiej porozumienie podpisał gen. Robert Lamezan de Salins ${ }^{4}$.

Postanowienia traktatu weszły w życie 10 stycznia 1920 r. Dzień później Polska i Niemcy zawarły w Paryżu porozumienie o opuszczeniu i czasowym zajęciu strefy granicznej między Polską a Niemcami. Porozumienie podpisali ze strony polskiej Leon Janta Połczyński, gen. Tadeusz Rozwadowski i Kazimierz Olszowski, zaś ze strony Niemiec Ernst von Simson. Celem porozumienia było unikanie wszelkich nieporozumień, które mogłyby powstać podczas opuszczania i przekazywania przez Niemcy terenów przyznanych Polsce. Obie strony zagwarantowały porozumienie i przestrzeganie postanowień traktatu pokojowego, jak również nieprzekraczanie ustalonej linii demarkacyjnej. Polskie oddziały mogły przekroczyć linię demarkacyjną dopiero po wyraźnym zezwoleniu przewodniczącego Komisji Granicznej. Zajęcie miejscowości i terenów nie mogło szkodzić gospodarczym interesom ludności ${ }^{5}$. Po tych ustaleniach władze polskie przejmowały przyznane tereny. W dniu 19 stycznia 1920 r. do Nowego Miasta Lubawskiego wkroczył uroczyście oddział Wojska Polskiego dowodzony przez por. Wybrańca ${ }^{6}$. W tym samym dniu od godz. $10^{00}$ wojska niemieckie rozpoczęły wymarsz z Lubawy i o godz. $13^{00}$ ostanie niemieckie oddziały przekroczyły most w Rodzonem udając się do Iławy. O godz. $15^{00}$ do miasta wkroczył uroczyście z muzyką pluton ułanów pod dowództwem por. Ptaszka ${ }^{7}$. Przekazywanie przejmowanych terenów odbywało się na ogół bez zakłóceń i zgodnie z planem. Rozpoczęło się 17 stycznia 1920 r., a zakończyło 2 lutego $1920 \mathrm{r}$. Nie zanotowano starć między polskimi i niemieckimi oddziałami. Były jedynie nieznaczące przekroczenia, które wynikały ze słabego oznakowania granicy. Punktem zapalnym był dworzec w Gardei, na terenie którego Polacy chcieli zorganizować polską kontrolę graniczną, co według strony niemieckiej nie było jeszcze możliwe. Mimo tego silne polskie patrole składające się z żołnierzy Armii Hallera podejmowały kolejne próby, trafiały jednak na zdecydowany opór Niemców. Po wycofaniu się rozstawily przed dworcem stanowisko z karabinem maszynowym. Przekazanie mostu na Wiśle na trasie kolejowej Malbork - Smętowo przebiegało bez problemów. Zachodnią część przejęli Polacy, zaś wschodnią obsadziła niemiecka Straż Graniczna ${ }^{8}$.

Przekazywanie administracji przejętych przez Polskę terenów odbywało się zgodnie z polsko-niemieckim porozumieniem z dnia 14 listopada 1919 r. o tym-

4 Gen. Lamezan de Salins był szefem Polskiej Misji Wojskowej w Berlinie, zob. A. Wojtaszak, Generalicja Wojska Polskiego 1918-1926, Warszawa 2012, s. 538.

5 Geheimes Staatsarchiv Preußischer Kulturbesitz, Berlin-Dahlem (GStA PK), I. HA Rep I. 77 Tit. 856, Nr 23 k. 150.

A. Korecki Nowe Miasto w czasach Drugiej Rzeczypospolitej (1920-1939) s. 153, w: Nowe Miasto Lubawskie zarys dziejów, red. M. Wojciechowski, Nowe Miasto Lubawskie, 1992.

J. Śliwiński, Lubawa. Z dziejów miasta i okolic, Olsztyn 1992, s. 153.

8 PA AA R95956 bp. Odpis sprawozdania z przekazania Polsce terenów Rejencji Kwidzyńskiej z 5.2.1920 r. 
czasowym uregulowaniu spraw urzędników. Według przepisów tego porozumienia niemieccy urzędnicy, którzy byli zatrudnieni w dniu 15 października 1919 r. w niemieckich urzędach położonych na terenach przekazywanych Polsce na mocy traktatu pokojowego, pozostawali na swoich urzędach przez okres 2 miesięcy, liczony od ostatniego dnia miesiąca, w którym zaczął obowiązywać traktat pokojowy, czyli do końca marca $1920 \mathrm{r}$. Rząd polski zastrzegł sobie możliwość zwolnienia poszczególnych urzędników. Do czasu likwidacji rząd polski przejął wszystkie dotychczas działające urzędy. Urzędnicy nie byli zobowiązani do złożenia przysięgi wierności Państwu Polskiemu, lecz mieli złożyć pisemne oświadczenie, że będą lojalnie wykonywać swoje obowiązki ${ }^{9}$. Przed wymarszem niemieckie oddziały przekazywały władzę polskim komisarzom. Polacy ogólnie nie życzyli sobie pozostania niemieckich urzędników. W szczególności wymieniono wszystkich starostów. Przekazywanie urzędów odbywało się bez problemów, jedynie skargi zgłaszał starosta lubawski. Podjęte natychmiast wyjaśnienia nie potwierdziły skarg ${ }^{10}$.

Jeszcze przed rozpoczęciem prac komisji granicznych Niemcy podejmowali działania w celu przesunięcia przyszłych granic na swoją korzyść. Niemiecki Sztab Generalny w listopadzie 1919 r. zaproponował niemieckiemu MSZ, aby w trakcie prac komisji uzyskiwać od strony polskiej zgodę na przesunięcie granic w zamian za budowę różnego rodzaju obiektów (cukrownie, tartaki, elektrownie, szkoły, kościoły itp.). Możliwość realizacji takich zamierzeń upatrywano w zainteresowaniu pomysłem osób z kręgu polskiego przemysłu, budownictwa, posiadaczy ziemskich i spekulantów nieruchomości. Należało do nich dotrzeć i nakreślić potencjalne zyski. Należało również dotrzeć do kręgu posłów i przedstawić im możliwości zysku. Planowano wykorzystać kontakty osobiste, by dotrzeć do osób podejmujących decyzje. W sprawie budowy linii kolejowych wskazywano na przedsiębiorcę Stelmachowskiego, który był zainteresowany współpracą i posiadał znaczne wpływy w polskim sejmie ${ }^{11}$.

Niemiecka ludność Działdowa nie chciała się pogodzić z postanowieniami traktatu pokojowego. Delegacja mieszkańców w dniu 9 października 1919 r. udała się do Berlina, aby w ambasadzie francuskiej spotkać się z gen. Dupontem. Delegacja miasta pod przewodnictwem superintendenta Barczewskiego przedstawiła wniosek o pozostawienie Działdowa i okolic w granicach Niemiec lub włączenia do terenów plebiscytowych. Dupont odpowiedział, że ich wnioski są spóźnione, gdyż traktat pokojowy został już podpisany i nie można go zmienić. Zdaniem generała, jeżeli można było cokolwiek zmienić, to jedynie podczas delimitacji granicy ${ }^{12}$. De-

9 GStA PK I. HA Rep A 200 Löbau, bp. odpis porozumienia z 14.11.1919 r.

10 PA AA R95956 bp. Odpis sprawozdania z przekazania....

1 GstA PK I. HA. Rep. 77 Tit. 856 nr 234 k. 374 i 375.

12 PA AA, R 95860, bp. Odpis pisma Prezydenta Rejencji Olsztyńskiej z 16.10.1919 r. 
legacja powiatu nidzickiego, do którego należało Działdowo, udała się w dniu 20 listopada 1919 r. do Prezydenta Rzeszy Niemieckiej z prośbą, aby podjął działania o włączenie Działdowa do terenów plebiscytowych. Delegacja wyraziła swoje stanowisko, że Działdowo zostało oddane Polsce, ponieważ linia kolejowa, która biegnie przez miasto łączy Polskę z Gdańskiem. Delegacja zaproponowała, żeby w zamian za pozostawienie Działdowa w granicach Niemiec, strona niemiecka podczas obrad komisji granicznej zaproponowała zobowiązanie do wybudowania linii kolejowej na odcinku Mława-Lidzbark ${ }^{13}$. W dniu 6 grudnia 1919 r. Prezydent Rejencji Olsztyńskiej przedstawił Ministrowi Spraw Wewnętrznych Niemiec propozycję, by włączyć Działdowo do terenów plebiscytowych w zamian za równoczesne włączenie do terenów plebiscytowych miasto Zülz (obecnie Biała) z Rejencji Opolskiej. Włączenie Zülz do terenów plebiscytowych miało spełnić żądania strony polskiej, która twierdziła, że ludność tego miasta jest w większości polska. Prezydent rejencji olsztyńskiej dowodził, że ludność Zülz jest w przeważającej większości niemiecka i będzie głosować za pozostaniem w Niemczech. Jednocześnie był przekonany, że społeczeństwo Działdowa będzie głosować również za pozostaniem przy Niemczech $^{14}$. Pomysł Prezydenta Rejencji Olsztyńskiej nie znalazł poparcia Prezydenta Rejencji Opolskiej, który mimo podobnego przekonania, że ludność Zülz jest w przeważającej większości niemiecka, nie zgodził się na eksperyment, którego wynik nie był do końca przesądzony ${ }^{15}$. Stanowczy protest złożył także burmistrz Zülz. Zwrócił uwagę na zaniepokojenie ludności jakie mogłoby wywołać włączenie ich miasta do terenów plebiscytowych. Zaniepokojenie to mogłaby wykorzystać polska propaganda ${ }^{16}$. Propozycja Prezydenta Rejencji Olsztyńskiej nie znalazła również poparcia Ministra Spraw Wewnętrznych ${ }^{17}$.

Do czasu wytyczenia granicy w terenie obowiązywała linia demarkacyjna. Granicę w terenie miała wytyczyć komisja wyznaczona przez Konferencję Ambasadorów, która nadzorowała również prace komisji. Dla ustalenia każdej granicy traktat pokojowy przewidywał powołanie jednej komisji. Każda komisja miała składać się z:

- komisarzy, których liczba i obywatelstwo ogólnie określał traktat pokojowy,

- ewentualnie wyznaczonych komisarzy,

- członków technicznych, których wyznaczano do wykonania prac w terenie, np. konieczne ustawienie i zabezpieczenie znaków granicznych itp.

- pracowników pomocniczych: topografowie, sekretarze, tłumacze itp.

13 PA AA, R 95860, bp. Odpis pisma Biura Prezydenta Rzeszy do MSZ z 20.11.1919 r.

14 GstA PK I. HA. Rep. 77 Tit. 856 nr 234 k. 377.

Ibidem k. 47 i 48.

Ibidem k. 49 i 50.

Ibidem k. 52. 
Wszyscy oni wchodzili w skład krajowej delegacji. Zasadniczo delegacja państw alianckich i stowarzyszonych miała się składać z: 1 komisarza, 1 tłumacza, 1 sekretarza i 1 topografa pomocniczego. W przypadku wydłużenia granicy lub trudności jej ustalenia, Konferencja Ambasadorów mogła zwiększyć skład delegacji dołączając dodatkowego wyznaczonego komisarza i wymaganą ilość technicznych członków i pracowników pomocniczych.

Delegacje państw zainteresowanych przewidziano do wykonania prac technicznych, w związku z czym ich składu nie określono wyraźnie. Miał on być dostosowany do wykonywanych zadań i określany każdorazowo przez komisję. Komisarze, jak również w miarę możliwości wyznaczeni komisarze, musieli być wyższymi oficerami lub równego stopnia, zaś członkowie techniczni - oficerami młodszymi lub równego stopnia. Sekretarze, topografowie pomocniczy powinni być podoficerami. Zasadniczo członkowie komisji mieli nosić mundury.

Członków komisji wyznaczała Konferencja Ambasadorów. Każdy komisarz za pośrednictwem konferencji był uwierzytelniany przez zaangażowane państwa. W przypadku potrzeby zwiększenia liczby wyznaczanych komisarzy komisja wnioskowała do Konferencji.

Komisje ustalające granicę $\mathrm{w}$ terenie miały za zadanie wyznaczyć ${ }^{18}$ :

- najpierw granice opisane w traktacie pokojowym,

- $\quad$ następnie granice według plebiscytów przewidzianych traktatem.

Komisje nie były uprawnione do samodzielnego wyznaczania granicy. Wyłączone z tego były istniejące już w sierpniu 1914 r. granice narodowe, gdzie zadanie komisji było ograniczone do oględzin słupów i znaków granicznych. Komisje mogły również w wyjątkowych przypadkach, gdy zezwalały na to szczególne postanowienia traktatu pokojowego, zmienić podział wymienionej miejscowości, pod warunkiem, że zmiana miała znikome znaczenie i za jednomyślną zgodą komisji.

Komisje miały się starać, aby jak najdokładniej przestrzegać ustaleń traktatu pokojowego i w miarę możliwości brać pod uwagę granice administracyjne, miejscowe interesy gospodarcze $\mathrm{z}$ wyłączeniem powodów narodowych, językowych czy religijnych. Komisje były władne do przygotowania protokołów lub ustaleń wszystkich regulacji prawnych wynikających z ustalenia granicy. Protokoły te lub ustalenia miały być ostateczne i wiążące dla zainteresowanych państw po ich zatwierdzeniu.

Komisarze państw sprzymierzonych wybierali spośród siebie prezydenta komisji. Dla każdej komisji Konferencja Ambasadorów wyznaczała dzień rozpoczęcia prac, który zasadniczo odbywał się w Paryżu. W tym dniu komisja określała swoją organizację (wybierała podkomisje itp.), wyznaczała plan pracy, ustalała ilość

18 PA AA R 95668 bp. Wytyczne Komisji Granicznej. 
wyznaczanych komisarzy i technicznych członków, jak również załatwiała sprawy zaopatrzenia materiałowego. Komisja wyznaczała także miejsce swoich obrad w miejscowości najbliżzzej ważnych punktów granicznych, jak również wyznaczała dzień rozpoczęcia prac. Komisja samodzielnie organizowała swoją pracę, jednakże tylko Konferencja Ambasadorów mogła zdecydować, czy w przypadku nieobecności (jednej lub wielu) delegacji państw niezainteresowanych, komisja może prowadzić działalność. Decyzje podejmowano większością głosów i były wiążące dla zainteresowanych państw.

Przewodniczącym komisji delimitacyjnej został francuski gen. Jules Dupont ${ }^{19}$, który w rozmowie $\mathrm{z}$ włoskim gen. Bencivegna stwierdził, że traktat pokojowy zawiera silne niesprawiedliwości wobec granicy niemiecko-polskiej, w związku z czym należało uwzględnić niemieckie żądania ${ }^{20}$. Komisja jako siedzibę wybrała Poznań, nie przyjmując wniosku Niemiec, żeby jej siedzibą był Berlin ${ }^{21}$.

Linię demarkacyjną, która czasowo miała zastąpić granicę wyznaczono w wielu miejscach w sposób niedokładny, co prowadziło do nieporozumień i konfliktów. Tak było w przypadku jeziora Trupel. Według strony niemieckiej jezioro należało w całości do Niemiec, a później do terenu plebiscytowego. Natomiast według strony polskiej, która opierała swoje stanowisko na podziale jeziora z 1903 r., należało w połowie do Polski, gdyż podział przekazywał połowę jeziora powiatowi lubawskiemu, który w całości został przekazany Polsce. Jezioro Trupel było dzierżawione przez niemieckiego rybaka Wilhelma Kanowskiego, któremu polscy żołnierze nie pozwalali dokonywać połowów na polskiej części jeziora. W lutym $1920 \mathrm{r}$. polscy żołnierze ostrzelali Kanowskiego podczas połowów i zmusili do sprzedaży połowów na polskiej stronie, jak również zatrzymali jego sieci. Następnie zmusili go do przeniesienia sieci na niemiecką stronę jeziora ${ }^{22}$.

W skład Podkomisji Granicznej do wyznaczenia granicy Prus Wschodnich wchodzili:

- $\quad$ przewodniczący ppłk Tonini - komisarz włoski,

- płk Boger - komisarz angielski,

- $\quad$ kpt. Durand - komisarz francuski zastępujący nieobecnego ppłk Gardana,

- $\quad$ mjr Sataro Takahashi - komisarz japoński,

- Wiktor Kulerski - komisarz polski (redaktor naczelny „Gazety Grudziądzkiej") $)^{23}$

19 GStA PK I. HA Rep I. 77 Tit. 856, Nr 235 k. 44. Odpis informacji francuskiego Ministerstwa Wojny z dnia 26.11.1919 r. o mianowaniu gen. Dupont na przewodniczącego komisji granicznej.

20 GStA PK I. HA Rep I. 77 Tit. 856, Nr 234 k. 246.

21 GStA PK I HA Rep. 77 Tit. 856, Nr 235 k. 81.

22 GStA PK I HA Rep. 77 Tit. 856, Nr 235, band II k. 249 i 250.

23 Postać Wiktora Kulerskiego przedstawił stronie niemieckiej starosta grudziądzki, który opisał go jako wroga Niemiec. Kulerski był właścicielem i redaktorem naczelnym „Gazety Grudziądzkiej”, w której pisał „nienawistne 
- $\quad$ mjr von Schickfus - komisarz niemiecki.

Uprawnienia podkomisji Prusy Wschodnie były takie same jak innych podkomisji, jednak nie mogła ona decydować o przydziale całych gmin do zainteresowanych państw, jedynie ich części i to za zgodą wszystkich komisarzy. $\mathrm{Na}$ pytanie gen. Duponta, czy rząd niemiecki dopuszcza możliwość wymiany całych miejscowości, które w trakcie plebiscytu głosowały za Niemcami, komisarz niemiecki stwierdził, że jest to wykluczone. W związku z tym gen. Dupont określił, że obiektami wymiennymi mogą być tylko części miejscowości (kolonie, folwarki) z polską ludnością albo osobne pola i lasy. Na posiedzeniu 15 października $1920 \mathrm{r}$. podkomisja podzieliła granicę Prus Wschodnich na 4 odcinki:

- Odcinek I od przecięcia drogi Nidzica-Mława z dawną granicą niemiecko-rosyjską na wschód od Białut do punktu spotkania granicy gminy Groszki i Lewałd Wielki z granicą powiatów Ostróda i Nidzica.

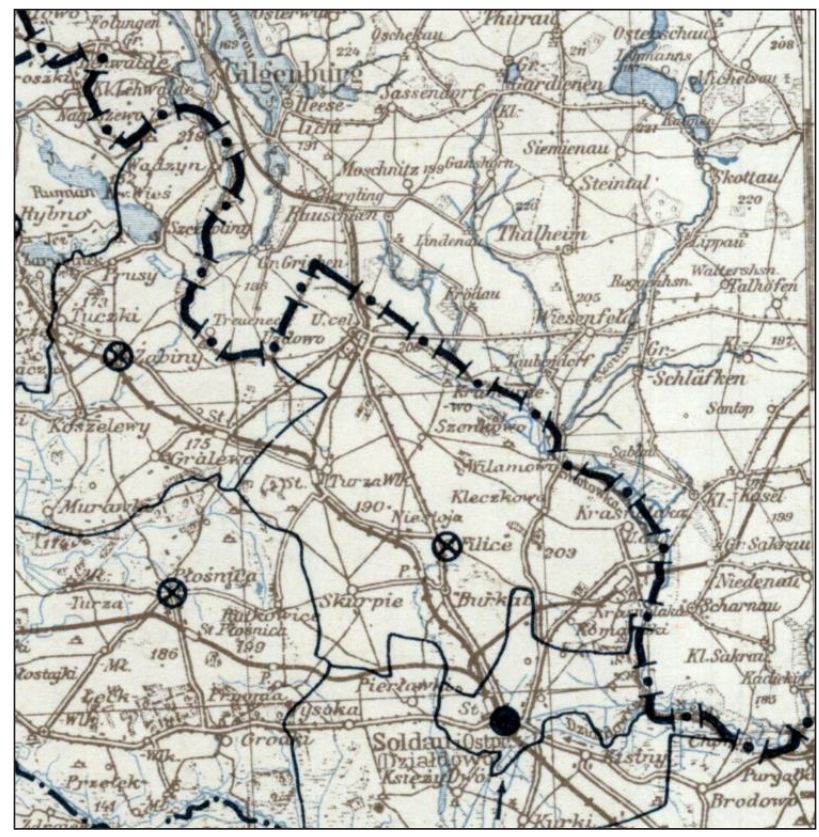

http://www.mapy.eksploracja.pl/

artykuły przeciwko wszystkiemu co niemieckie”. Wcześniej Wiktor Kulerski był nauczycielem i posłem do Reichstagu. Jako redaktor był uwikłany w wiele procesów, po których częściowo był uniewinniony, a częściowo skazany. Na początku wojny jego ataki na Niemcy były znaczne i z biegiem czasu coraz ostrzejsze. Był przewodniczącym Polsko-Katolickiej Partii Ludowej, na którą miał duży wpływ dzięki swoim artykułom w gazecie, która ukazywała się w nakładzie 40000-60 000 egz. Jednocześnie W. Kulerski był zagorzałym przeciwnikiem Narodowej Demokracji. Wypowiadał się, że może swobodnie objąć stanowisko ministerialne w nowym polskim rządzie, ale odmawiał, bo chciał zachować prawo do krytyki. Był często krytykowany przez umiarkowanych Polaków za radykalne poglądy, co mu nie przeszkadzało w dalszym pisaniu podburzających artykułów. PA AA, R 95958, bp. Odpis pisma Prezydenta Rejencji Kwidzynskiej z 12.12.1919 r. 
- $\quad$ Odcinek II dalej na wschód do jeziora Karaś (do przecięcia drogi Iława-Biskupiec Pomorski) z południową granicą powiatu Susz.

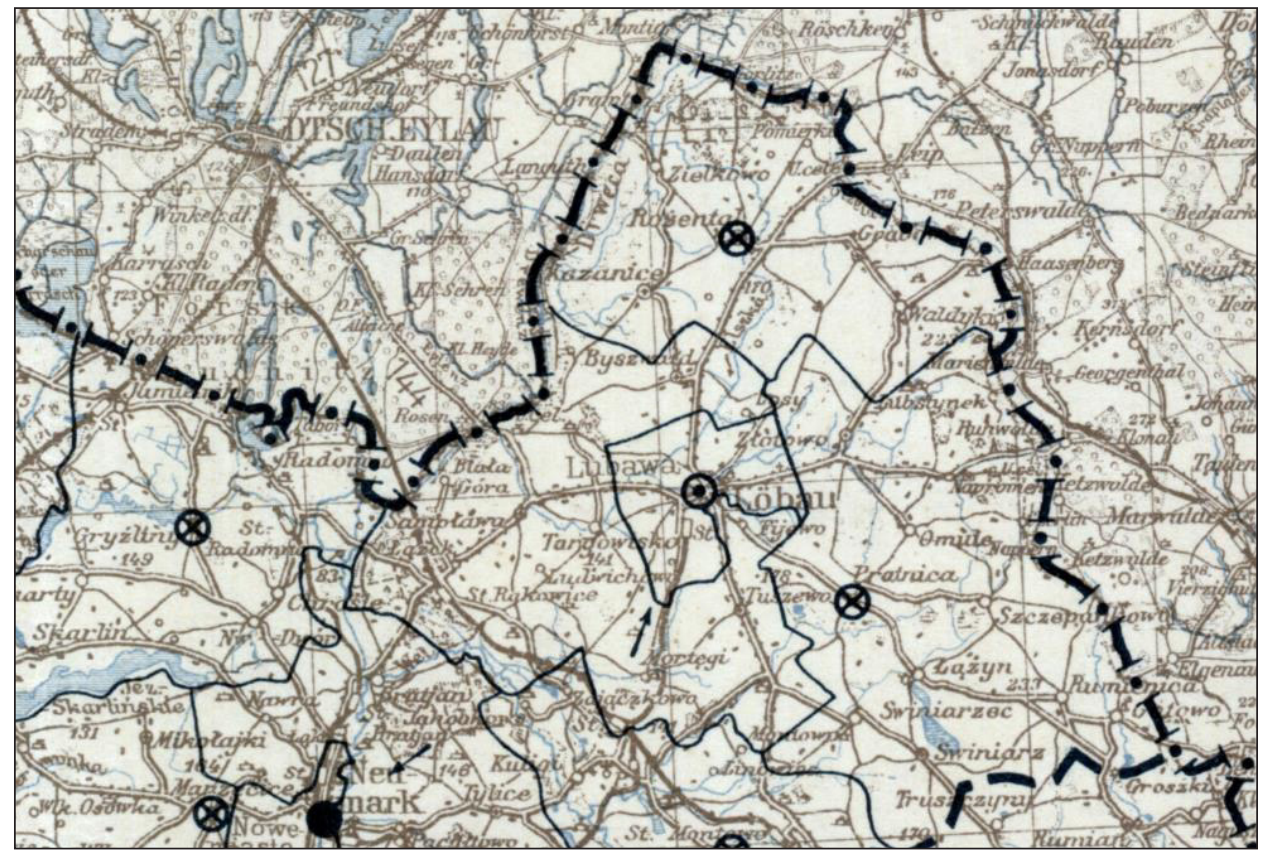

- Odcinek III dalej do wschodniej granicy gminy Gardeja ze wschodnią granicą powiatu Malbork.

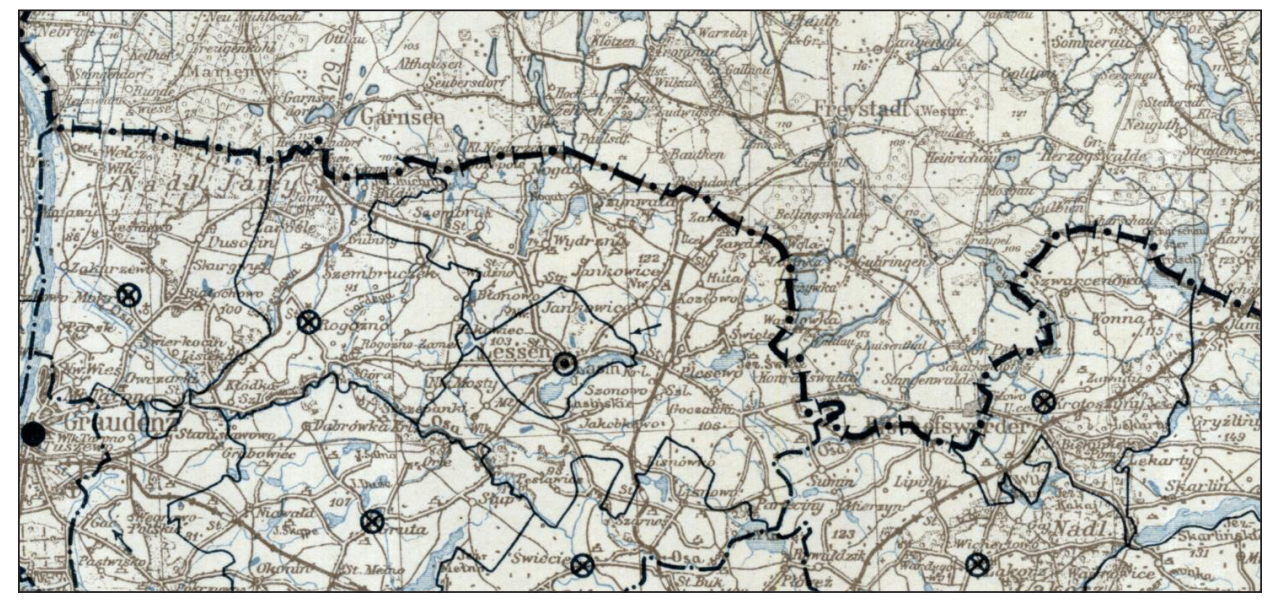


- $\quad$ Odcinek IV do miejsca, gdzie Polska, Niemcy i Gdańsk postawią znak graniczny (odcinek Wisły).

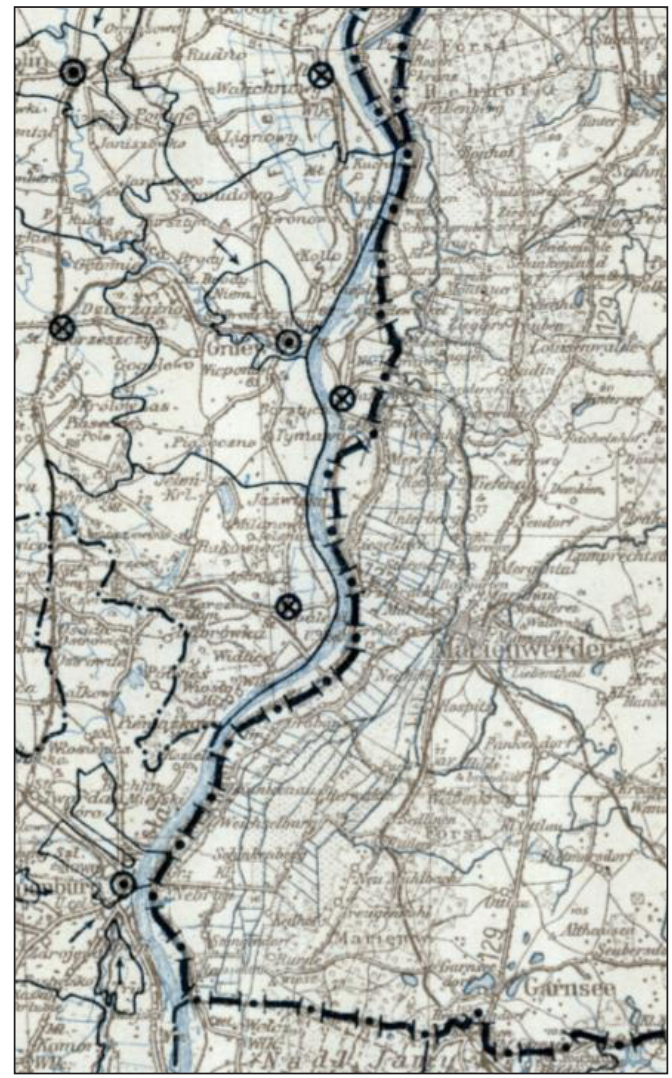

Początkowo zaplanowano rozpocząć wytyczanie granicy od Wisły do dawnej granicy rosyjsko-niemieckiej, jednak drażliwe problemy spowodowały zmianę decyzji gen. Duponta. Były to różnice zdań dotyczące Napromka oraz cypla Szkotówki, niedokładne dane dotyczące linii granicznej przy Białuty, niepokoje w rejonie Działdowa. Dupont postanowił możliwie szybko definitywnie określić granice na tych odcinkach. Brakowało również opinii rzeczoznawców dotyczących biegu Wisły. Na posiedzeniu w dniu 17 października 1920 r. w Grudziądzu zaproponował wszystkim delegatom przyspieszenie prac, które miało polegać na przekazaniu decyzji o przebiegu granicy od podkomisji do głównej komisji. Oznaczało to skrócenie prac, ale uniemożliwiało składanie protestów, na co nie chciała zgodzić się delegacja niemiecka. Przewodniczący komisji dopuścił wtedy możliwość składania protestów od decyzji komisji. 
Na tym samym posiedzeniu gen. Dupont podjął dyskusję dotyczącą przekazania Polsce trzech miejscowości: Napromek, Lubstynek i Groszki. Miejscowości te przypadły Polsce na podstawie decyzji Konferencji Ambasadorów z dnia 15 sierpnia 1920 r. w związku z opowiedzeniem się ludności tych miejscowości w trakcie plebiscytu za przynależnością do Polski ${ }^{24}$. Do dnia podjętej dyskusji strony nie upomniały się o przekazanie tych miejscowości. Wszyscy komisarze opowiedzieli się za przekazaniem miejscowości do 24 października 1920 r. Niemiecki komisarz złożył protest motywując to, że wyznaczony termin był zbyt krótki i nie miał wytycznych rządu niemieckiego. Jednocześnie podniósł argument, że nie może w żadnym wypadku oddać leżącego po niemieckiej stronie majątku kościelnego Napromek, który większością 4/5 głosował za Niemcami. Po połączeniu głosów gminy Napromek i majątku głosujący za Niemcami posiadali większość 27 głosów. Komisarz niemiecki wniósł o przesunięcie terminu przekazania na 31 października 1920 r. i czasowe pozostawienie majątku kościelnego Napromek przy Niemczech. Dupont poparł niemiecki wniosek, ale jednocześnie odrzucił polski wniosek o przydzielenie Polsce drogi z Wygody do majątku kościelnego Napromek. Przekazanie tych miejscowości Polsce opóźniało się, gdyż w drugiej połowie sierpnia przy granicy polsko-niemieckiej toczyły się ciężkie walki lub miał miejsce przemarsz wojsk polskich biorących udział w pościgu za wycofującymi się wojskami sowieckimi. W dniu 20 sierpnia 1920 r. Prezydent rejencji olsztyńskiej zaniepokojony sytuacją po polskiej stronie pisał do niemieckiego Ministra Spraw Zagranicznych, że oficjalne przekazanie trzech miejscowości może jedynie nastąpić na drodze umowy między zainteresowanymi rządami. Strona polska próbowała już przejąć miejscowości na podstawie porozumienia między dowódcami wojsk. Komisja plebiscytowa, która wyjeżdżała, podjęła w dniu 21 sierpnia 1920 r. decyzję o przekazaniu całego terenu plebiscytowego pod niemiecką administrację. Jednocześnie niemiecki poseł w Warszawie, graf Obendorff, uzgodnił z polskim rządem, aby wojska polskie i niemieckie uznały dotychczasową granicę terenów plebiscytowych jako linię demarkacyjną. Niemieckie MSZ zobowiązało prezydenta rejencji w Olsztynie, by nie podejmował żadnych czynności w tej sprawie, gdyż sposób przekazania miejscowości zostanie uzgodniony w trakcie prac komisji granicznej ${ }^{25}$.

24 Przed podjęciem dyskusji na posiedzeniu gen. Dupont powiadomił majora Livoniusa, że na następnym posiedzeniu komisji poruszy temat trzech miejscowości, które Niemcy mieli przekazać Polsce i będzie wnosił o wyznaczenie terminu przekazania na 25.10.1920 r. Mjr Livonius odpowiedział, że w żadnym wypadku przekazanie nie może się odbyć 25.10 .1920 r. i jeszcze w tym samym dniu sporządził notę, w której prosił o przesunięcie terminu przekazania na 30.10.1920 r. Celem działań Livoniusa było „uratowanie” majątku Napromek, który głosował za pozostaniem w Niemczech, przed przekazaniem go do Polski. Gdyby strona polska sprzeciwiała się niemieckim żądaniom, miał wnosić o przyznanie obiektu wymiennego. PA AA, R 95718, bp. Sprawozdanie mjr Livoniusa z dnia 19.10.1920 r. Niemiecka delegacja w dniu 23.11.1920 r. spotkała się w Dąbrównie z właścicielem majątków Napromek i Lubstynek. Fundacja kościelna Kloster Bergeschen Stiftungsguetern Klein-Lobstein und Klein-Nappern zobowiązała się nie dochodzić odszkodowań z tytułu przejścia ich majątku do Polski w zamian za pozostawienie majątku Klein-Nappern (Napromek) w Niemczech. PA AA, R 95718, bp. Pismo niemieckiego Ministra ds. Nauki, Sztuki i Oświaty z dn. 10.12.1920 r.

25 PA AA, R 95718, bp. Memorandum dotyczące przynależności Napromka, Lubstyka i Groszek z dnia $09.10 .1920 \mathrm{r}$. 
Następnym niewyjaśniony problem stanowiła przynależność tzw. cypla Szkotówki. Już w styczniu 1920 r. podczas obrad w Paryżu mjr Livonius zwrócił uwagę przewodniczącemu obrad gen. Le Rondowi na nieprecyzyjne sformułowanie traktatu pokojowego oraz załączonej do niego mapy w sprawie przynależności cypla Szkotówki. Chodziło o zapis stąd dawna granica między Prusami Zachodniemi a Prusami Wschodniemi, dalej granica między powiatami ostródzkim a niborskim, biegiem Szkotewki $w$ dót rzeki, dalej $w$ górę Nidy aż do punktu położonego mniej-więcej 5 kilometrów na zachód od Białut, a najbardziej zbliżonego do dawnej granicy rosyjskiej. W rzeczywistości Szkotówka nie biegła na granicy powiatów nidzickiego i ostródzkiego, lecz około $2 \mathrm{~km}$ na zachód. Strona niemiecka dowodziła, że postanowienia traktatu pokojowego w żadnym wypadku nie przewidywały przyznania Polsce cypla, który tworzyła Szkotówka. Tak wycięty cypel miał szerokości 2 km i długości 17 km i zawarte w nim ważne punkty miejscowość Kownatki i jezioro Szkotówka powinny zostać wyszczególnione w opisie. Mapa załączona do traktatu przedstawiała cypel po stronie niemieckiej. Podobna mapa była załączona również do porozumienia z 25 listopada 1919 r. Pozostawienie cypla po stronie polskiej tworzyłoby gospodarcze problemy 14 gmin znajdujących się na terenie cypla, które byłyby odcięte przez poprzecinane drogi. W związku z tym już w Paryżu postanowiono, że cypel pozostanie na terenie plebiscytowym ${ }^{26}$. Mieszkańcy cypla zdecydowaną większością głosowali za pozostaniem przy Niemczech i Polska straciła jakiekolwiek roszczenia do tego terenu. Komisja graniczna poparła niemieckie stanowisko.

Przed przystąpieniem do obrad podkomisja graniczna odbyła 30 października 1920 r. w Dąbrównie posiedzenie, na którym wysłuchiwała życzenia zainteresowanych mieszkańców odcinka I. Podkomisja przyjmowała wnioski i omawiała z mieszkańcami ich sytuację $e^{27}$.

Podczas ustalania przebiegu granicy na odcinku I strona niemiecka zgłosiła wniosek o przekazanie, jej zdaniem, czysto niemieckich gmin: Purgałki, Wilamowo, Uzdowo, Klin, Nowa Wieś i Wądzyn. Komisja nie miała odpowiednich obiektów do wymiany (jedynie na wschód od Białut dysponowała działką oraz małym kawałkiem lasu należącym do gminy Wola). Polski komisarz Wiktor Kulerski odpowiadając na niemiecki wniosek przedstawił komisji obraz niemieckiego terroru podczas przygotowań i plebiscytu na terenie Malborka oraz Olsztyna i wnioskował o przyznanie Polsce całego terenu łąk na południe od Woli, młyna Borowo, 14 gmin położonych w cyplu Szkotówki i dużego terenu na wschód od Wądzynia. Po twardych rokowaniach komisja ustaliła następujący przebieg granicy. Niemcom przypadły: na północ od Pugałki położone łąki i dalej do Iłowa tereny na wschód od Wilamowa, tereny

26 GStA PK I HA Rep. 77 Tit. 856, Nr 235, band II k. 416 i 417.

27 Die Neue Preussische Zeitung (Kreuz-Zeitung) nr 518 z 3.11.1920 „Die Festsetzung der deutsch-polnischen Grenze”. 
po obu stronach drogi Zabłocie-Wilamowo, mocno sporny młyn Borowo, kolonia Klin i łąka położona na północ jeziora Panzer. Polsce przyznano działkę na wschód od Białut, którą niemiecki właściciel i tak sprzedał Polakowi, działkę leśną należącą do gminy Wola na wschód od Purgałki, leżącą na północ od granicy powiatu drogę między Działdowem i Laskiem. Odnośnie polskich roszczeń do cypla Szkotówki gen. Dupont stwierdził, że sprawa została wyjaśniona przez komisję plebiscytową i nie czuje się on upoważniony do dokonywania jakichkolwiek zmian. Wystosuje jednak do Konferencji Ambasadorów notę, w której przedstawi polskie żądania, chociaż dodał, że nie należy się spodziewać, iż Konferencja ambasadorów zadecyduje inaczej. W rzeczywistości gen. Dupont tak sporządził notę, że w Paryżu nie można było zdecydować inaczej. Polski wniosek został odrzucony. Linię granicy oparto na środkowej linii rzeki. Po ustaleniach dotyczących I odcinka granicy niemiecki komisarz orzekł, że niemiecka komisja może być zadowolona ${ }^{28}$.

Komisja Graniczna obrady dotyczące ustalenia przebiegu odcinka II, obejmującego ziemię lubawską, zaplanowała na 10 grudnia 1920 r. Wcześniej, w dniach 22-27 listopada 1920 r. członkowie przebywali na obszarach przygranicznych przyjmując wnioski ludności. Ze strony niemieckiej żądano pozostawienia na terytorium Niemiec miejscowości Czerlin i Wiśniowo. Strona polska wnosiła o przyznanie Polsce miejscowości: Lewałd Wielki, Odmy, Elgnowo i Jagodziny, jak również miejscowości Czerlin. Delegacja polska chciała uzyskać także obszar, w którym spotkały się linie kolejowe Toruń-Iława i Działdowo-Iława, wraz z położonym między tymi liniami lasem nadleśnictwa Rudzienice (ok 2200 ha). Jako uzasadnienie ostatniego żądania podnoszono interesy ekonomiczne. Delegacji niemieckiej udało się obalić polskie argumenty i obszar połączenia linii kolejowych oraz położone pomiędzy nimi obszary leśne przyznano Niemcom. Miejscowości Czerlin i Wiśniowo przyznano Polsce, gdyż strona niemiecka nie miała możliwości ich wymiany na inne ${ }^{29}$.

Ostateczna decyzja w sprawie przebiegu granicy polsko - niemieckiej na północnym odcinku od Groszek do przecięcia drogi Szeplerzyzna - Jamielnik została podjęta na posiedzeniu komisji granicznej w pełnym składzie w Poznaniu w dniu 13 grudnia 1920 r. Od decyzji komisji nie przewidywano odwołania. Podział granicy obejmował ${ }^{30}$ :

Dla Niemiec: Lewałd Wielki - Odmy - Odmy Kolonia - Elgnowo Kolonia - Jagodziny - Jagodziny Kolonia - Wygoda - Glaznoty - Zajączki Młyn - Zajączki - Majątek i Gmina Lipowo - Juńcza - Lichotka - Majątek Gierłoż - Dąbrówno - Gromoty - Mały Bór - Tchórzanka - Rodzone - Pustkowie - Tartak Smolniki - Leśnictwo Nowy Ostrów - Leśnictwo Katarzynki - Radomek - Szeplerzyzna.

28 PA AA, R 95718, bp. Sprawozdanie z posiedzeń Komisji sporządzone przez niemieckiego komisarza z dnia 22.11.1920 r.

29 PA AA, R 95719, bp. Protokół posiedzenia Komisji z 30.12.1920 r.

30 GStA PK, I. HA Rep I. 77 Tit. 856, Nr 57, Band 3 s. 2 i 3. Odpis powiadomienia Komisji ds. Ustalenia Granicy. 
Dla Polski: Groszki - Gutowo - Rumienica - Szczepankowo - Czerlin - Napromek - Lubstynek - Zakurzewo - Wiśniewo - Wałdyki - Grabowo - Kołodziejki - Pomierki - Polska Gierłoż - Zielkowo Młyn - Zielkowo - Kazanice - Raczek - Sampława - Biała Góra - Pustki - Radomno - Ludwichowo Głodowo - Orłowo - Jamielnik.

Niemcy zostali zobowiązani do opuszczenia przyznanych Polsce terenów do dnia 15 stycznia 1921 r. (sobota) do godz. $11^{00}$.

Wśród miejscowości przydzielonych Polsce w ww. dokumencie znajdują się Groszki, Lubstynek i Napromek, które przypadły Rzeczypospolitej po plebiscycie przeprowadzonym 11 lipca 1920 r. Mimo oddania ich Polsce, Niemcy próbowali odzyskać je podczas ustalania granicy przez Komisję Graniczną. Wcześniej, 16 września 1920 r. Prezydent Rejencji Olsztyńskiej pisał do Ministra Spraw Wewnętrznych Prus, że Polacy nie przejęli przedmiotowych miejscowości i proponował ich wymianę $w$ trakcie obrad komisji ${ }^{31}$.

W dniu 2 kwietnia 1921 r. Komisja ustaliła dalszy odcinek granicy w powiecie lubawskim $^{32}$. Polsce przydzielono 5 gospodarstw należących do wsi Koniecwałd, część niezamieszkałą terenu majątku Osówko, jedno gospodarstwo i teren niezamieszkały należące do wsi Piotrowice Wielkie. Niemcom przypadły majątek Zazdrość, który dotychczas należał do powiatu lubawskiego i z powiatu grudziądzkiego wieś Tymawa Mała oraz dwa gospodarstwa należące do wsi Krzywka, jak również gospodarstwo ze wsi Zawada. Ogólnie Polska otrzymała 6 gospodarstw o łącznej powierzchni 206 ha, zaś Niemcy 10 gospodarstw o łącznej powierzchni 239 ha. Strona polska nie była zadowolona z podjętej decyzji i złożyła wobec niej protest. Przejęcie przyznanych terenów wyznaczono na 20 kwietnia 1921 r. godz. $11^{100}$.

Jeszcze przed oficjalnym przekazaniem, bo 15 kwietnia starosta lubawski zażądał od właściciela majątku Zazdrość dostarczenia zaległych dostaw zboża. Zaległość oceniono na 281 cetnarów żyta, 88 cetnarów pszenicy i 20 cetnarów jęczmienia. W przypadku niewywiązania się z nałożonych dostaw wyznaczono karę w wysokości 800 tys. Marek Polskich. Z niemieckiej strony urząd skarbowy w Suszu zażądał od właścicieli 5 gospodarstw ze wsi Koniecwałd, które przypadły Polsce, zapłaty podatku w łącznej wysokości 34.991 Marek Niemieckich. O powyższych sprawach został powiadomiony Prezydent Rejencji w Malborku, który stwierdził, że obie strony miały prawo do żądania należności. Zaległe dostawy starosta lubawski wyznaczył również właścicielom innych gospodarstw przekazywanych do Niemiec (Tymawa Mała, Krzywka, Zawada). W dniu 19 kwietnia 1921 r. oddział polskich żołnierzy otoczył przekazywane miejscowości i zażądał natychmiastowej

31 GStA PK, I. HA Rep I. 77 Tit. 856, Nr 57, Band 3, s. 407.

32 Ibidem, s. 78, odpis powiadomienia z 5.4.1921 r. 
zapłaty podatków. Tylko w jednym przypadku zapłacono podatek. Zarekwirowano konie, bydło i narzędzia rolnicze. Wiadomość o ściągnięciu podatków dotarła na niemiecką stronę dopiero następnego dnia, co uniemożliwiło Niemcom przeprowadzenie działań represyjnych. Tylko dzięki szybkiej akcji policji zarządzonej przez Prezydenta Rejencji udało się Niemcom „uratować” 4 dobre konie i 6 krów. Resztę majątku, który mógłby być zarekwirowany przez Niemców polska ludność przeprowadziła przez granicę. Bezpośrednio po przejęciu miejscowości ich mieszkańcy zwrócili się do nowych władz o pomoc w odzyskaniu zarekwirowanego mienia. Dzięki porozumieniu obu stron udało się już następnego dnia wymienić na nowej granicy zarekwirowane sztuki ${ }^{33}$.

W traktacie pokojowym granica na Wiśle została określona w art. 28 i 97. Artykuł 28 ustanawiał, że granica Polski z Niemcami od Nogatu będzie przebiegać głównym korytem żeglownym Wisły w górę, dalej południową granicą powiatu suskiego ku wschodowi do punktu jej zetknięcia się z dawną granicą Prus Wschodnich. Natomiast art. 97 traktatu pokojowego stanowił, że Główne Mocarstwa Sprzymierzone i Stowarzyszone oznaczą granicę między Prusami Wschodnimi i Polską na tym obszarze, pozostawiając w każdym razie Polsce na całym odcinku Wisły zupełny i całkowity nadzór rzeki, włączając w to brzeg wschodni na takiej przestrzeni, która może okazać się konieczną do jej uregulowania i ulepszenia ${ }^{34}$.

Stanowisko polskie zakładało dążenie do przejęcia powiatów położonych na prawym brzegu Wisły, co dawałoby możliwości pełnej kontroli żeglugi, regulacji i melioracji rzeki. W owym czasie Wisła nie była rzeką w całości uregulowaną. Należało $\mathrm{w}$ wielu miejscach przebudować wały przeciwpowodziowe. Wałami opiekował się Kwidzyński Zarząd Wałowy, który był finansowany przez zarząd rzeki. Nie można było prowadzić zarządu rzeki bez możliwości wpływu na wały. Prowadzenie robót regulacyjnych wymagało swobodnego dostępu do prawego brzegu rzeki. Na tym brzegu znajdował się materiał potrzebny do umacniania wałów (faszyna, kamień) oraz mieszkali robotnicy. Regulacja Wisły była ściśle związana z melioracją Niziny Kwidzyńskiej. Położone na tej nizinie rzeki należało włączyć pod kontrolę urzędu regulacyjnego Wisły. Dla Polski duże znaczenie miały także względy strategiczne ${ }^{35}$.

Prace nad ustaleniem granicy na odcinku Wisły rozpoczęły się po zakończeniu plebiscytu. Komisja plebiscytowa w Kwidzynie przesłała Konferencji Ambasadorów sprawozdanie z wynikami plebiscytu wraz z propozycjami, które zostały przekazane do zaopiniowania dla komisji technicznej i geograficznej. W dniu 26 lipca 1920 roku Konferencja Ambasadorów podjęła decyzję w kluczowej sprawie

\footnotetext{
33 Ibidem, s. 57-60.

34 Traktat pokoju miedzy mocarstwami sprzymierzonemi i skojarzonemi i Niemcami, podpisany w Wersalu dnia 28 czerwca 1919 roku, Dz. U. 1920, nr 35, poz. 200.

35 Plebiscyty na Warmii, Mazurach i Powiślu w 1920 roku, dokument 310.
} 
wynikającej z art. 97 (akapit 4) traktatu pokojowego. Konferencja uznała, że zapis „zupełny i całkowity nadzór rzeki” oznacza przynależność państwową. Przy wytyczaniu odległości od brzegu Wisły miały być brane pod uwagę potrzeby przeprowadzenia aktualnych i niezbędnych prac regulacyjnych, nie zaś plany modernizacyjne na przyszłość. Przewidywano, że terytorium polskie będzie obejmowało tereny należące do organów nadzoru i regulacji rzeki. Konferencja ustaliła, że zachodnia granica Prus Wschodnich będzie się zaczynać na północy od trójstyku granicy Polski, Wolnego Miasta Gdańska oraz Prus Wschodnich, następnie w kierunku południowym zasadniczo po linii tworzonej przez wody rzeki Wisły i jej wschodniego brzegu. Jednocześnie ustalono:

- Biała Góra pozostaje w Niemczech. O przynależności śluzy na Nogacie i portu zdecyduje komisja graniczna.

- $\quad$ Miejscowości: Nowe Lignowy, Kramary, Dwór Bursztych, Janowo i Małe Pole będą polskie. Ich wschodnie granice będą stanowiły granicę Prus Wschodnich.

- $\quad$ Miejscowość Korzeniowo zostaje niemiecka. Port będzie polski.

- $\quad$ Położone na wschodnim brzegu Wisły urządzenia mostu w Opaleniu będą polskie ${ }^{36}$.

Od powyższych postanowień Konferencji Ambasadorów przewodniczący niemieckiej delegacji pokojowej złożył w dniu 28 lipca 1920 r. protest, w którym wywodził, że strona niemiecka rozumiała nadzór nad rzeką jako rodzaj międzynarodowej służebności. Zdaniem Niemiec granica powinna przebiegać wzdłuż głównego nurtu rzeki. Przyznanie zaś Polsce terytorium na wschodnim brzegu Wisły miało praktycznie blokować niemieckiej ludności dostęp do rzeki. Konferencja wraz z takim ustaleniem granicy winna była określić zasady korzystania z rzeki poprzez wydanie stosownych przepisów ${ }^{37}$.

Odpowiedź przewodniczącego Konferencji Ambasadorów, Julesa Cambona, potwierdzała wcześniejsze ustalenia Konferencji. Jednocześnie postanowiono, że ostateczne wytyczenie granicy przeprowadzi Komisja Graniczna, która dokona tego w terenie, po wysłuchaniu opinii obu stron, jak również rzeczoznawców i inżynierów ${ }^{38}$.

Decyzja Konferencji Ambasadorów została oficjalnie przedstawiona Polsce i Niemcom w Paryżu 12 sierpnia 1920 r. Do czasu ustalenia przez Komisję Graniczną miała obowiązywać linia demarkacyjna. Przedstawiciele obu państw byli zobligowani przejąć linię demarkacyjną, każdy ze swojej strony, do południa 16 sierpnia $1920 \mathrm{r}$. Wsie przyznane Polsce miały być przekazane przez dowództwo wojsk sprzymierzonych o godz. $10^{00}$. Komisji ustalającej granice wyznaczono termin do 3 miesięcy ${ }^{39}$.

36 PA AA R 95737 bp. Poufne pismo Przewodniczącego Niemieckiej Delegacji Pokojowej do niemieckiego MSZ z 27.07.1920 r. Nr IV Po 8520. W podpisie Göppert.

37 PA AA R 95737 bp. Niemiecka wersja protestu złożonego przez niemiecką delegację pokojową w Paryżu 28 VII 1920 r. W podpisie Göppert.

38 PA AA R 95737 bp. tłumaczenie na język niemiecki pisma z 12.08.1920 r.

39 PA AA R 95737 bp. odpis protokołu. 
Niemcy uznawali Odcinek Wisły jako bardzo ważny i jeszcze przed rozpoczęciem prac komisji w tym zakresie przeprowadzali przedsięwzięcia przygotowawcze. Jednym z nich była podróż zapoznawcza całej komisji Wisłą (ze strony polskiej uczestniczył hrabia Szembek). Niemcy byli zainteresowani, aby sprzymierzonym pokazać Wisłę w okresie najniższych stanów. Udało im się to w październiku 1920 r., gdy nie padało od kilku tygodni. W trakcie podróży występowali niemieccy rzeczoznawcy, którzy zapoznali komisję z problemami regulacji rzeki, zagrożeniami powodziowymi i utrzymaniem wałów powodziowych ${ }^{40}$.

W dniu 27 listopada 1920 r. przewodniczący komisji gen. Dupont w trakcie posiedzenia Konferencji Ambasadorów w Paryżu wniósł o powołanie rzeczoznawcy ds. żeglugi rzecznej. Było to spowodowane żądaniem polskiego komisarza, który stwierdził, że linia granicy, która została określona w piśmie z 12 sierpnia 1920 r., nie zapewnia stronie polskiej kontroli nad regulacją i możliwości prowadzania modernizacji. W związku z żądaniami strony polskiej Niemcy, 13 grudnia 1920 r., dostarczyli komisji materiały, które miały zawierać argumenty do obalenia polskiego stanowiska. Dupont stwierdził, że niemieckie wnioski są trochę przesadzone, ale materiał uznał za ciekawy i miał przekazać go powołanemu rzeczoznawcy ${ }^{41}$.

Następny materiał dotyczący Wisły niemiecka delegacja przekazała gen. Dupontowi w dniu 19 stycznia $1921 \mathrm{r}$. Autorem tego materiału był radca Niese, który dowodził, że dla prowadzenia przez stronę polską prac regulacyjnych Wisły wystarczy pas brzegowy (poza wałami) o szerokości 40-50 m. Dupont, 16 stycznia 1921 r., przekazał Konferencji Ambasadorów notę, w której popierał polską tezę, że Wisła dla Niemiec miała mniejsze znaczenie niż dla Polski. Wisła stała się dla Polski główną drogą zaopatrzenia i utrzymanie jej w stanie żeglownym będzie stanowiło dla niej bardzo ważne zadanie. Nota zawierała 9 pytań, na które musiała odpowiedzieć komisja przed podjęciem decyzji o ustanowieniu granicy na Wiśle:42 1. Granica Wolnego Miasta Gdańska była już ustalona, mimo to należało jeszcze określić w którym miejscu tej granicy znajduje się styk z granicą polsko-niemiecką. Na to pytanie winni odpowiedzieć rzeczoznawcy. Konferencja Ambasadorów określiła, że granicą w terenie będzie linia, która będzie biegła między rzeką i wałem. Komisja miała się kierować zasadą, że każdy wał, który służył gminie jako ochrona przeciwpowodziowa, winien być przydzielony państwu, do którego ta gmina należy. Wyjątek stanowiły wały, które służyły do regulacji żeglugi. Takie wały przypadały Polsce.

2. Czy dla utrzymania kontroli żeglugi na rzece jest potrzebne posiadanie wszystkich wałów? Zdaniem strony polskiej, aby kontrolować ruch na rzece

$40 \quad$ PA AA R95718 bp. Sprawozdanie niemieckiej komisji ds. ustalenia granicy z 27.11.1920 r.

41 PA AA R95719 bp. Sprawozdanie niemieckiej komisji ds. ustalenia granicy z 30.12.1920 r.

42 PA AA R 95738 bp. Nota gen. Dupont z 6.12.1920 r. w języku niemieckim. 
trzeba utrzymywać wały. Gdy wały będą zaniedbane, woda może wystąpić z koryta rzeki i żegluga będzie niemożliwa. Strona niemiecka uzasadniała jednocześnie, że do utrzymania wałów potrzebny jest szeroki pas przed nimi, gdyż stamtąd pozyskuje się materiał do ich budowy.

3. Czy lepszym rozwiązaniem byłaby granica wzdłuż górnego grzebienia wałów? Jeżeli wał nie jest życiowo niezbędny dla Polski, to jaka jest właściwa dla Niemiec szerokość pasa od rzeki do wału?

4. Co w przypadku dwóch wałów?

5. Czy najbardziej oddalony od rzeki wał może samodzielnie ochronić wyznaczone wsie? Jeżeli nie, czy Niemcy otrzymają jakiś okres czasu na jego poprawienie?

6. Port Korzeniowo przydzielono Polsce, wieś Korzeniowo pozostanie przy Niemczech. Do kogo będzie należał wał?

7. Czy jest możliwe danie Polsce prawa do przeprowadzania niezbędnych prac modernizacyjnych na rzece, pozostawiając jednocześnie dla Niemiec nizinę.

8. Czy możliwe jest przekazanie zadania utrzymania wałów organizacji powołanej na mocy umowy międzynarodowej?

9. Czy melioracja Wisły będzie ważna dla Polski?

Nota miała być tylko do akt francuskiego biura głównego, ale przez przeoczenie francuskiego oficera trafiła także do Niemców. Wywołała ona oburzenie strony niemieckiej oraz zmobilizowała wszystkie urzędy i organy do przygotowania materiałów potwierdzających niemieckie twierdzenia. Już 2 lutego 1921 r. niemiecka delegacja odpowiedziała na notę gen. Duponta, przedstawiając memorandum dotyczące granicy na Wiśle. Przeciwstawiano się stanowisku Duponta wskazując, że wały przeciwpowodziowe nie mają nic wspólnego z nadzorem nad żeglugą. Ochronę przed powodzią stanowi cały system wałów wzdłuż, nie tylko jeden wał. Podwójne wały wybudowano w miejscach szczególnego zagrożenia. Wały i tereny wokół należą do towarzystw przeciwpowodziowych i zmiana przynależności państwowej wałów sparaliżowałaby ich pracę ${ }^{43}$. Memorandum przetłumaczono na wszystkie języki członków komisji, a wersję francuską przekazano Konferencji Ambasadorów.

W dniu 28 marca 1921 r. podano nazwiska powołanych rzeczoznawców: Mr. H.J. Luke z Wielkiej Brytanii, M. Robert z Francji i M. Edoardo Sassi z Włoch. Zgodnie z zarządzeniem gen. Duponta rzeczoznawcy mieli zapoznać się z terenem osobno w obecności polskiego lub niemieckiego rzeczoznawcy ${ }^{44}$.

Do reprezentowania interesów Polski wyznaczono rzeczoznawcę Okyńskiego, stronę niemiecką reprezentował dr de Thierry. W dniu 10 maja 1921 r. odby-

43 PA AA R95738 bp. pismo niemieckiej delegacji do przewodniczącego komisji granicznej gen. Duponta z 1.02.1921.

44 PA AA R95720 bp. Sprawozdanie niemieckiej komisji ds. ustalenia granicy z 1920 r. 
ło się pełne posiedzenie komisji granicznej, które prowadził przewodniczący, gen. Dupont, który przekazał komisji i rzeczoznawcom następujące wytyczne ${ }^{45}$ :

Nota konferencji Ambasadorów z 12 sierpnia 1920 r. wyznaczyła granicę. Zlecała jednocześnie komisji wprowadzenie koniecznych zmian potrzebnych Polsce do wykonania przyznanych jej praw w artykule 97 traktatu, przy czym Polsce musi być pozostawiona granica na taką głębokość (na co najmniej całym odcinku, na którym tworzy granicę Wisła) jaka jest wymagana dla regulacji rzeki i prowadzenia prac poprawczych na jej wschodnim brzegu.

Rola rzeczoznawców polegała więc wyłącznie na podaniu komisji zmian, które należy wprowadzić na liniach granicznych wyznaczonych pismem Konferencji Ambasadorów z dnia 12 sierpnia 1920 roku i które są konieczne, aby wprowadzić je zgodnie z przyznanymi Polsce prawami w artykule 97 Traktatu Wersalskiego.

$\mathrm{W}$ trakcie posiedzenia obie zainteresowane strony przekazały rzeczoznawcom komisji własne opracowania uzasadniające swoje stanowiska. Autorem polskich opinii był radca Ingarden. Zgodnie z planem pracy komisji rzeczoznawcy państw niezainteresowanych mieli pisemnie ustosunkować się do stanowisk polskich i niemieckich w terminie do dnia 31 maja 1921 r. Pod koniec maja trzej eksperci przekazali przewodniczącemu komisji swoje opinie. Ich objętość przekraczała 30 stron. Głównym pytaniem, na które musieli odpowiedzieć było: czy rzeka, wał i nizina tworzą niepodzielną całość? Według stanowiska Niemiec niepodzielną całość stanowiły jedynie wał i nizina. Natomiast regulacja rzeki nie wymagała posiadania wałów i niziny. Opinia francuskiego rzeczoznawcy (Robert) podzielała stanowisko polskie i proponowała przyznanie Polsce prawie całej niziny Kwidzyńskiej. Rzeczoznawcy z Włoch (Sassi) i w szczególności z Wielkiej Brytanii (Luke) podzielali stanowisko niemieckie. W dniu 4 czerwca 1921 roku gen. Dupont zarządził na 15 czerwca pełne posiedzenie komisji w Poznaniu, która miała zająć się wyznaczeniem granicy na Wiśle. Na tym posiedzeniu Dupont zamierzał ocenić wnioski rzeczoznawców, czy mieszczą się one w ramach uprawnień komisji. Całe opinie rzeczoznawców miały być dołączone do protokołu komisji i przekazane Konferencji Ambasadorów. Ponieważ 2/3 opinii rzeczoznawców podzielały stanowisko, niemiecka delegacja wniosła protest do przewodniczącego komisji. W dniu 15 czerwca 1921 r. na posiedzeniu komisji Dupont określił zadania stwierdzając, że nota Konferencji Ambasadorów z 12 sierpnia 1920 roku stanowi podstawę pracy komisji. Wszelkie zmiany winny być czynione, aby zagwarantować Polsce prawa wynikające z postanowień art. 97 traktatu pokojowego, z zastrzeżeniem, że mieszkańcy niziny pozostają niemieccy. Strona niemiecka zrozumiała stwierdzenie Duponta, że każda zmiana będzie odbywała się na niekorzyść Niemiec. Zażądano

45 PA AA R95739 bp. Sprawozdanie niemieckiej komisji ds. ustalenia granicy z 17.07.1920. 
więc, aby np. w przypadku przyjęcia opinii rzeczoznawcy francuskiego, strona niemiecka otrzymała prawo do odszkodowania od strony polskiej. Takim żądaniom stanowczo sprzeciwiła się strona polska. Dupont postanowił postawić pod głosowanie sprawę niepodzielności niziny kwidzyńskiej, dzieląc ją na dwa pytania:

- $\quad$ czy rzeka, wał i nizina tworzą niepodzielną całość?

- $\quad$ czy określona przez notę konferencji ambasadorów (z dnia 12 sierpnia 1920 r.) granica wystarczy Polsce dla wykonywania praw określonych art. 97 traktatu pokojowego?

Do głosowania nad pierwszym pytaniem przystąpiono bez dyskusji. Wynik głosowania był następujący: na "nie” głosowali komisarze niemiecki, brytyjski, włoski i japoński. Na „tak” głosowali komisarze polski i francuski. Przed drugim głosowaniem protest złożyła delegacja polska. Protest zarzucał postępowanie komisji niezgodne z postanowieniami konferencji ambasadorów. Mimo protestu głosowanie nad drugim pytaniem kontynuowano. $\mathrm{Na}$ "tak” wypowiedzieli się komisarze niemiecki, brytyjski, włoski i japoński. Na „nie” głosował komisarz francuski, zaś polski komisarz wstrzymał się od głosu (stwierdził, że nie był upoważniony przez rząd do głosowania na drugie pytanie). Taki wynik głosowania świadczył, że komisarze popierali opinie swoich rzeczoznawców. Komisarz japoński popierał stanowisko Niemiec.

Wyniki obrad komisji były niekorzystne dla Polski. W specjalnej nocie do Konferencji Ambasadorów rząd Polski złożył wniosek o odwołanie rzeczoznawców i powołanie rzeczoznawców pochodzących z USA. Komisja delimitacyjna przerwała swoje obrady. Komisja Ambasadorów nie uwzględniła polskiego wniosku i poleciła komisji podjęcie przerwanych obrad ${ }^{46}$.

$\mathrm{Z}$ decyzji komisji delimitacyjnej nie byli zadowoleni także Niemcy. W dniu 6 lipca 1921 roku w Ministerstwie Spraw Zagranicznych w Berlinie odbyło się posiedzenie, na którym dyskutowano możliwości pertraktacji z Polską. Wcześniej, 24 czerwca 1921 roku, brytyjski komisarz ppłk Boger złożył propozycję porozumienia, która zakładała następujące zmiany:

1. Granica będzie przebiegać między rzeką a wałami, przy czym cała nizina kwidzyńska wraz z wałami pozostanie przy Niemczech,

2. Niemcy oddadzą Polsce obszar na południe od Iławy,

3. Niemcy zobowiążą się, że w ciągu 5 lat przeprowadza na swój koszt regulację Wisły od Wielki Wełcz do śluzy Biała Góra,

4. Niemcy opłacą inżynierów powołanych przez konferencję ambasadorów,

5. Polska zobowiąże się do przeprowadzenia robót regulacyjnych powyżej i poniżej odcinka przeznaczonego dla Niemiec,

46 Z. Lietz, Plebiscyt na Powiślu, Warmii i Mazurach w 1920 roku, Warszawa 1958, s. 246. 
6. Niemcy zobowiążą się do wypłaty odszkodowania dla miejscowych polskich posiadaczy, którzy wyjadą do Polski oraz Niemcy zobowiążą do opłacania lodołamaczy.

Zobowiązania wynikające z powyższych propozycji oszacowano na ok. 138 mln. marek. Jednocześnie oceniono, że okres 5 lat na przeprowadzenie prac regulacyjnych na odcinku ok. $42 \mathrm{~km}$ może być za krótki. Okres ten winien wynosić 10 lat. Należałoby również uzyskać gwarancję od Polski i Wolnego Miasta Gdańska, że także w tym samym czasie przeprowadzą swoje prace regulacyjne, gdyż $\mathrm{w}$ przeciwnym razie niemieckie regulacje nie przyniosłyby zamierzonego skutku. Przedstawiciel niemieckiego MSZ podsumowując spotkanie stwierdził, że Niemcy są gotowe do poniesienia obciążeń finansowych. Jednak brakowało potwierdzenia, czy propozycja Bogera zostanie zaakceptowana przez Polskę. Przyjęto więc postawę wyczekiwania na dalszy przebieg wydarzeń. Dotychczas polskie stanowisko nie miało poparcia komisji delimitacyjnej. Polski wniosek do Konferencji Ambasadorów strona niemiecka oceniła jako mający małe szanse powodzenia. Strona niemiecka miała bronić postanowień komisji, a dopiero w przypadku niekorzystnych dla Niemiec zmian podjaćc rozmowy na temat propozycji Bogera ${ }^{47}$.

Ostateczne posiedzenie komisji w sprawie granicy na Wiśle odbyło się 27 sierpnia 1921 roku. Zdecydowano na nim, że granica na odcinku Wisły między Polską a Niemcami przebiegać będzie 20 metrów od rzeki. Polsce przyznano wsie: Nowe Lignowy, Kramary, Dwór Bursztych, Janowo i Małe Pole, jak również port w Korzeniowie, z którego mogli korzystać także Niemcy, przyczółek mostowy na Wiśle pod Opaleniem oraz dworzec kolejowy w Gardei, z którego mogli korzystać Niemcy. Dopiero 31 marca 1922 roku komisja delimitacyjna przekazała wytyczoną granicę wojsku polskiemu i niemieckiemu ${ }^{48}$.

47 PA AA R30684 karty K021614 - 21621.

48 Z. Lietz, op. cit., s. 246 i 247. 
Tabela przedstawiająca stanowiska powołanych rzeczoznawców.

\begin{tabular}{|c|c|c|c|}
\hline Pytanie & \begin{tabular}{|l|} 
Angielski rze- \\
czoznawca Mr. Luke
\end{tabular} & $\begin{array}{l}\text { Włoski rzeczoznaw- } \\
\text { ca Edoardo Sassi }\end{array}$ & Francuski rzeczoznawca Mr. Robert \\
\hline $\begin{array}{l}\text { 1) Na czym polega } \\
\text { regulacja Wisły? } \\
(\text { art. } 97,4 .)\end{array}$ & $\begin{array}{l}\text { Regulacja rzeki Wisły } \\
\text { dzieli się na części: } \\
\text { regulacja stanów } \\
\text { wysokich, średnich } \\
\text { i niskich. }\end{array}$ & $\begin{array}{l}\text { Inaczej przyszłe stu- } \\
\text { dia i regulacja Wisły } \\
\text { będą miały za cel } \\
\text { budowę wałów coraz } \\
\text { bardziej oddalonych } \\
\text { od rzeki. }\end{array}$ & $\begin{array}{l}\text { Wały przeciwpowodziowe i mechani- } \\
\text { zmy utrzymania niskiego stanu wód } \\
\text { zostały utworzone, do wypełniania } \\
\text { wzajemnych zadań w nowych warun- } \\
\text { kach, wskutek prac uzupełniających, } \\
\text { które państwo Polskie ma zamiar i obo- } \\
\text { wiązek wspierać (strona 5, III na dole). } \\
\text { Jeżeli w wyniku regulacji na niskim } \\
\text { stanie wód uda się, osiągnąć nawet } \\
\text { tylko zamierzony wynik w niemiec- } \\
\text { kim projekcie, to znaczy, jeżeli za- } \\
\text { pewniona jest najmniejsza głębokość } \\
1,80 \text { m na średnim niskim stanie } \\
\text { wód, to wydaje mi się, że rzeka bę- } \\
\text { dzie wstanie sprostać komunikacji. }\end{array}$ \\
\hline $\begin{array}{l}\text { 2) Czego potrzebuje } \\
\text { Polska do zachowa- } \\
\text { nia swoich praw wy- } \\
\text { nikających z artykułu } \\
97,4 \text { ? }\end{array}$ & $\begin{array}{l}\text { Polska potrzebuje do- } \\
\text { stępu, aby kontrolować } \\
\text { brzegi na pewnych } \\
\text { odcinkach stanów } \\
\text { średnich, gdyż po- } \\
\text { trzebuje składać tam } \\
\text { materiały do utrzyma- } \\
\text { nia i linii brzegowej. } \\
\text { Linia ta w żadnym } \\
\text { wypadku nie powinna } \\
\text { przebiegać } 10 \mathrm{~m} \text {. od } \\
\text { wału. Wystarczająca } \\
\text { jest odległość ok. } 50 \\
\text { m. od brzegu. }\end{array}$ & $\begin{array}{l}\text { Uznaję, że dla że- } \\
\text { glugi jest konieczne } \\
\text { nadbrzeże, przynaj- } \\
\text { mniej jego część, dla } \\
\text { utrzymania (polskiej) } \\
\text { kontroli rzeki lub } \\
\text { dla poszczególnych } \\
\text { ulepszeń. }\end{array}$ & $\begin{array}{l}\text { Konieczność, aby nie dopuścić do } \\
\text { powstania takiej sytuacji, w moim } \\
\text { uznaniu przemawia za podjęciem } \\
\text { decyzji, która nakaże rozsądne zasa- } \\
\text { dy hydro-elektryki i przyzna Polsce } \\
\text { wały przeciwpowodziowe i nizinę } \\
\text { Kwidzyńską. }\end{array}$ \\
\hline $\begin{array}{l}\text { 3) Czy wały przeciw- } \\
\text { powodziowe mają coś } \\
\text { wspólnego z żeglugą? }\end{array}$ & $\begin{array}{l}\text { Z tego wynika, że } \\
\text { Polska nie ma po- } \\
\text { trzeby kontrolowania } \\
\text { wałów przeciwpowo- } \\
\text { dziowych (punkt 2c) }\end{array}$ & $\begin{array}{l}\text { Czy może rzeczoznaw- } \\
\text { ca mýleć i przekony- } \\
\text { wać, że wały i żegluga } \\
\text { są ze sobą połączone? } \\
\text { Uważam, że systemy } \\
\text { ochrony przed powo- } \\
\text { dzią i regulacji rzeki są } \\
\text { od siebie niezależne, } \\
\text { w szczególności żeglugi. }\end{array}$ & $\begin{array}{l}\text { Chociaż są położone poza odcinkami } \\
\text { niskiego stanu zbiornika wody, to od- } \\
\text { działują na utrzymanie i poprawę rze- } \\
\text { ki i także z punktu widzenia żeglugi. } \\
\text { Odwrotnie prace regulacyjne obecne } \\
\text { i w przyszłości na odcinkach średnich } \\
\text { i niskich w niskich zbiornikach wody } \\
\text { mają wpływ na brzeg i nadbrzeże } \\
\text { przed wałami i na stan wody. }\end{array}$ \\
\hline $\begin{array}{l}\text { 4) Czego potrzebują } \\
\text { Niemcy? }\end{array}$ & $\begin{array}{l}\text { Niemcy potrzebują } \\
\text { znaczną część nad- } \\
\text { brzeża, aby uzyskać } \\
\text { utrzymanie wałów } \\
\text { i pól. }\end{array}$ & $\begin{array}{l}\text { Uznaję również, że } \\
\text { i to co jest niezbędne } \\
\text { dla ochrony powo- } \\
\text { dziowej i wałów, jest } \\
\text { także do utrzymania } \\
\text { wałów, ochrony wa- } \\
\text { łów, jest także } \\
\end{array}$ & $\begin{array}{l}\text { Jeżeli wał, chociaż w rzeczywistości } \\
\text { przeznaczam go dla Polski, byłby } \\
\text { obiecany dla Niemiec, to pas naj- } \\
\text { więcej } 20 \text { m. wzdłuż rzeki byłby wy- } \\
\text { starczający do utrzymania i naprawy } \\
\text { wałów. }\end{array}$ \\
\hline
\end{tabular}




\begin{tabular}{|c|c|c|c|}
\hline Pytanie & \begin{tabular}{|l|} 
Angielski rze- \\
czoznawca Mr. Luke
\end{tabular} & $\begin{array}{l}\text { Włoski rzeczoznaw- } \\
\text { ca Edoardo Sassi } \\
\end{array}$ & Francuski rzeczoznawca Mr. Robert \\
\hline & & $\begin{array}{l}\text { zapasem ziemi dla } \\
\text { wzmocnienia tam. }\end{array}$ & \\
\hline $\begin{array}{l}\text { 5) Port w Korzenio- } \\
\text { wie? }\end{array}$ & $\begin{array}{l}\text { Nizina z wałami } \\
\text { tworzy całość pod } \\
\text { względem technicz- } \\
\text { nym i gospodarczym, } \\
\text { jak położenie portu } \\
\text { w Korzeniowie }\end{array}$ & $\begin{array}{l}\text { Niewielki port bez } \\
\text { nadbrzeża w Korze- } \\
\text { niowie ma żywotne } \\
\text { znaczenie dla niziny. } \\
\text { Myślę, że komisja } \\
\text { w tym szczególnym } \\
\text { przypadku ponosząc } \\
\text { odpowiedzialność za } \\
\text { pozostawienie Niem- } \\
\text { com władzy nad tere- } \\
\text { nami i wodami, winna } \\
\text { jednocześnie przyznać } \\
\text { prawo korzystania } \\
\text { z portu polskim lodo- } \\
\text { łamaczom, które będą } \\
\text { szukały schronienia. }\end{array}$ & $\begin{array}{l}\text { W tym przypadku, gdy Niemcom } \\
\text { przypadną wszystkie wały, mieliby } \\
\text { Polacy podporządkowany interes } \\
\text { posiadania portu w Korzeniowie. } \\
\text { Zadaniem portu w Korzeniowie } \\
\text { byłoby udzielanie schronienia lodo- } \\
\text { łamaczom, co mógłby czynić, gdyby } \\
\text { przynależał do Niemiec. }\end{array}$ \\
\hline $\begin{array}{l}\text { 6) } 5 \text { wsi nadwiślań- } \\
\text { skich i przyczółek } \\
\text { mostowy w Opale- } \\
\text { niu? }\end{array}$ & $\begin{array}{l}\text { Oddzielenie } 5 \text { wsi } \\
\text { i przyczółka mosto- } \\
\text { wego, linii kolejowej } \\
\text { Opalenie - Kwidzyn, } \\
\text { jak również łąki } \\
\text { na północy niziny } \\
\text { będących jednolitą } \\
\text { całością stanowi naj- } \\
\text { gorsze niebezpieczeń- } \\
\text { stwo dla niziny. }\end{array}$ & $\begin{array}{l}\text { Nizina, wały (zachod- } \\
\text { nie - zewnętrzne) } \\
\text { i pas ziemi o szeroko- } \\
\text { ści minimum } 10 \mathrm{~m} \text {. } \\
\text { musza być połączone. }\end{array}$ & $\begin{array}{l}\text { Obecnie zachodni wał jest widziany } \\
\text { jako ochrona niziny. Stary wschodni } \\
\text { wał, który wymaga poprawy, jest } \\
\text { w wielu miejscach osłabiony przez } \\
\text { ubytki ziemi. Po za tym jest niższy } \\
\text { o } 50 \mathrm{~cm} \text { niż nowy wał. }\end{array}$ \\
\hline $\begin{array}{l}\text { 7) Wielki i Mały } \\
\text { Wełcz? }\end{array}$ & $\begin{array}{l}\text { Oddzielenie wsi } \\
\text { Wielki i Mały Wełcz } \\
\text { od Niziny będzie } \\
\text { miało te same skutki } \\
\text { jak powyżej. } \\
\end{array}$ & & \\
\hline $\begin{array}{l}\text { 8) Proponowana } \\
\text { granica? }\end{array}$ & $\begin{array}{l}\text { Moim zdaniem ze } \\
\text { względów technicz- } \\
\text { nych granica powin- } \\
\text { na przebiegać środ- } \\
\text { kową linią rzeki. } \\
\text { W żadnym wypadku } \\
\text { nie powinna zbliżać } \\
\text { się na odległość } \\
\text { mniejszą niż } 10 \mathrm{~m} \text {. } \\
\text { do wałów. }\end{array}$ & $\begin{array}{l}\text { Linia granicy po- } \\
\text { winna przebiegać } \\
\text { pomiędzy zachodnim } \\
\text { wałem w odległo- } \\
\text { ści najmniej } 10 \mathrm{~m} \text {, } \\
\text { a brzegiem wyzna- } \\
\text { czonym przez roślin- } \\
\text { ność tam. }\end{array}$ & $\begin{array}{l}\text { Ten podział, teoretycznie, musi być } \\
\text { tak zrozumiany, że granica polskiego } \\
\text { obszaru winna być na naturalnym } \\
\text { obszarze zalewowym Wisły, tzn. } \\
\text { ślady powodzi Wisły na pagórkach } \\
\text { otaczających nizinę. }\end{array}$ \\
\hline
\end{tabular}


Tomasz Wyżlic, Die Grenze Ostpreußens zu Polen zwischen 1919-1922

\section{Zusammenfassung}

Der am 28. Juni 1919 im Spiegelsaal des Schlosses von Versailles unterzeichnete Friedensvertrag begründete eine neue politische Teilung Europas. Polen erhielt Woiwodschaft Poznań ohne Wschowa, Babimost, Międzyrzecze und Skwierzyna sowie den größten Teil Königlichen Preußens (insgesamt 45.463 Quadratkilometer mit etwas mehr als drei Millionen Einwohnern). Die Festlegung der Grenzen Polens erfolgte vor allem unter dem Druck des widerstrebenden britischen Premierministers David Lloyd George, der sich allen Lösungsversuchen widersetzte, die zur Stärkung der Rolle Frankreichs in Europa beitragen könnten. Die endgültige Festlegung der Grenze sollte den alliierten und assoziierten Mächten obliegen. Der Sejm der Republik Polen ratifizierte nach einer stürmischen Debatte am 31. Juli 1919 den Friedensvertrag mit Deutschland. Er trat am 10. Januar 1920 in Kraft. Der Friedensvertrag sah auch ein Volksbegehren in einem Teil Ost- und Westpreußens vor, das über die Zugehörigkeit von Ermland, Masuren und Powiśle zu Polen oder Deutschland entscheiden sollte. Erst nach dem Ende des Volksbegehrens begann die Grenzkommission mit den Abgrenzungsarbeiten. Der ungünstige Ausgang des Volksbegehrens führte dazu, dass die territorialen Errungenschaften Polens unbedeutend waren, und die Arbeit der Kommission konzentrierte sich auf die Abgrenzung der durch den Friedensvertrag festgelegten Grenzen, d.h. von der ehemaligen deutsch-russischen Grenze bis zur Weichsel, sowie auf den Abschnitt der Weichsel bis zur Freien Stadt Danzig.

\section{Tomasz Wyżlic, Eastern Prussia's border with Poland in the years 1919-1922}

\section{Summary}

Signed on 28 June 1919 in the Hall of Mirrors of the Palace of Versailles, this peace treaty established a new political order in Europe. Poland gained the Poznań lands, excluding Wschowa, Babimost, Międzyrzecz and Skwierzyna, and a larger part of the Royal Prussia (a total of $45463 \mathrm{~km}^{2}$ and a little over three million inhabitants). Determining Polish borders was a process largely affected by the British Prime Minister, David Lloyd George, who was reluctant in his attitude towards Poland. He opposed any solution that would increase the role of France in Europe. The final shape of the borders was to be a task of the Allied and Associated Powers. After a heated debate, the Legislative Sejm of Poland ratified a peace treaty with Germany on 31 July 1919. It took effect on 10 January 1920. The peace treaty also arranged a plebiscite in parts of Eastern and Western Prussia, which was to determine the Polish or German affiliation of Warmia, Masuria and Powiśle. Only after that event the Boundary Commission began its delimitation works. The results of the plebiscite were unfavourable for Poland as it gained only small territories. The commission in the field focused on establishing the borders in the light of the peace treaty, so along the former German-Russian border until the Vistula river and then along it up to the Free City of Danzig.

dr Tomasz Wyżlic

Instytut Północny im. Wojciecha Kętrzyńskiego w Olsztynie

\section{Bibliografia}

\section{Źródła archiwalne}

Das Geheime Staatsarchiv Preußischer Kulturbesitz Berlin - Dahlem - Tajne Archiwum Państwowe Fundacji Pruskiego Dziedzictwa Kulturowego

- $\quad$ sygn. HA Rep. 77 Staatsoberhaupt und oberste Staatsbehörden, Ministerien und Andere Zentralbehörden Preussens AB 1808.

Politisches Archiv des Auswärtigen Amts Berlin (PAAA) - Archiwum Polityczne Ministerstwa Spraw Zagranicznych Berlin

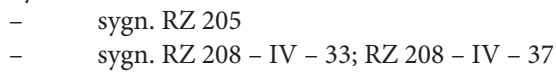




\section{Opracowania}

Korecki Andrzej

1992 Nowe Miasto w czasach Drugiej Rzeczypospolitej (1920-1939), w: Nowe Miasto Lubawskie. Zarys dziejów, red. M. Wojciechowski, Nowe Miasto Lubawskie.

Lietz Zygmunt

1958 Plebiscyt na Powiślu, Warmii i Mazurach w 1920 roku, Warszawa.

Wojtaszak Andrzej

2012 Generalicja Wojska Polskiego 1918-1926, Warszawa.

Wrzesiński Wojciech

1984 Warmia i Mazury w polskiej myśli politycznej, Warszawa.

1986 Plebiscyty na Warmii, Mazurach i Powiślu w 1920. Wybór źródeł, oprac. W. Wrzesiński, P. Stawecki, Olsztyn.

2010 Polska-Prusy Wschodnie. Plebiscyt na Warmii i Mazurach oraz na Powiślu w 1929 roku, Olsztyn. 